medRxiv preprint doi: https://doi.org/10.1101/2021.02.15.21251750; this version posted February 19, 2021. The copyright holder for this preprint (which was not certified by peer review) is the author/funder, who has granted medRxiv a license to display the preprint in It is made available under a CC-BY 4.0 International license.

\title{
Altered immunity to microbiota, B cell activation and depleted $\gamma \delta$ / resident memory $T$ cells in colorectal cancer
}

\author{
Alistair Noble ${ }^{* 1,2}$, Edward T Pring ${ }^{2,3}$, Lydia Durant ${ }^{2}$, Ripple Man ${ }^{3}$, Stella M Dilke ${ }^{2,3}$, Lesley Hoyles ${ }^{4}$, \\ Steve A James ${ }^{1}$, Simon R Carding ${ }^{1,5}$, John T Jenkins ${ }^{3}$, Stella C Knight ${ }^{2,3}$
}

${ }^{1}$ Gut Microbes \& Health Program, Quadram Institute Bioscience, Norwich, UK

${ }^{2}$ Antigen Presentation Research Group, Imperial College London, Northwick Park \& St. Mark's Campus, Harrow, UK

${ }^{3}$ St. Mark's Hospital, London North West University Healthcare NHS Trust, Harrow, UK

${ }^{4}$ Dept of Biosciences, Nottingham Trent University, Nottingham, UK

${ }^{5}$ Norwich Medical School, University of East Anglia, Norwich, UK

Running title: immune:microbiota interaction in colorectal cancer

*Correspondence to Stella C Knight, Antigen Presentation Research Group, Northwick Park \& St. Mark's Hospital, Level 7W, Watford Road, Harrow HA1 3UJ, UK.

Email: s.knight@imperial.ac.uk; Tel (44) 2088693494.

The authors declare no potential conflicts of interest

Funding: We acknowledge the support of the Biotechnology and Biological Sciences Research Council (BBSRC); this research was funded by the Quadram Institute BBSRC Institute Strategic Programme Gut Microbes and Health BB/R012490/1 and its constituent projects BBS/E/F/000PR10353 and BBS/E/F/000PR10356. Funding for A.N. and SCK was from London North West University Healthcare NHS Trust R\&D. 
medRxiv preprint doi: https://doi.org/10.1101/2021.02.15.21251750; this version posted February 19, 2021. The copyright holder for this preprint (which was not certified by peer review) is the author/funder, who has granted medRxiv a license to display the preprint in It is made available under a CC-BY 4.0 International license.

\section{Author Contributions}

A.N. and S.C.K. designed the studies and wrote the manuscript. A.N. and E.T.P. performed the experimental work and analyzed the data. L.D. and S.M.D. assisted with experimental work and data interpretation. L.H. and S.A.J. provided the bacterial/yeast strains and microbiota expertise. E.T.P., R.M. and J.T.J. recruited patients, provided clinical samples and contributed clinical insights into the study. S.R.C. contributed to study design and manuscript preparation. All authors provided input on the manuscript.

Abbreviations: CRC, colorectal cancer; Trm, resident memory T-cells; HC, healthy control; IBD, inflammatory bowel disease; IEL, intraepithelial lymphocytes; LPL lamina propria lymphocytes; IEM, intraepithelial microbes; TNF, tumor necrosis factor; IFN, interferon; DC, dendritic cell.

\section{Abstract}

We sought methods of rectifying microbiota:immune dysregulation as a route to prophylaxis and improved immunotherapy of colorectal cancer (CRC). CRC develops in gut epithelium, accompanied by low level inflammatory signaling, intestinal microbial dysbiosis and immune dysfunction. We examined populations of intraepithelial lymphocytes in non-affected colonic mucosa of CRC and healthy donors and circulating immune memory to commensal bacterial species and yeasts. Colonic tissue in CRC was significantly depleted of $\gamma \delta T$ cells and resident memory T cells, populations with a regulatory CD39-expressing phenotype. T cell memory responses to a panel of commensals were distinct in CRC, while B cell memory responses to several bacteria/yeast were significantly increased, accompanied by increased proportions of effector memory B cells, transitional B cells and plasmablasts in blood. IgA responses to mucosal microbes were unchanged. Our data describe a novel immune signature with similarities to and differences from that of inflammatory bowel disease. They implicate B cell dysregulation as a potential contributor to parainflammation and identify pathways of weakened barrier function and tumor surveillance in CRC-susceptible individuals. 
medRxiv preprint doi: https://doi.org/10.1101/2021.02.15.21251750; this version posted February $19,2021$. The copyright holder for this preprint (which was not certified by peer review) is the author/funder, who has granted medRxiv a license to display the preprint in perpetuity.

It is made available under a CC-BY 4.0 International license .

\section{Introduction}

Colorectal cancer (CRC) arises from a complex interplay between genetic, inflammatory, environmental and microbiome-related factors. CRC usually arises from adenomatous polyps derived from intestinal stem cells and can be caused by genetic mutations, including lesions in the adenomatous polyposis coli (APC) gene (associated with familial adenomatous polyposis) or mismatch repair genes (e.g. Lynch syndrome). Globally, in 2012 there were an estimated 1.4 million new cases and almost 700,000 deaths attributable to CRC. Around $2 \%$ of cases arise in those with inflammatory bowel disease (IBD) and $15 \%$ of IBD patients die from $\mathrm{CRC}^{1}$. Cancer is associated with low-grade or parainflammation ${ }^{2}$ and sustained raised levels of circulating pro-inflammatory cytokines, e.g. TNF- $\alpha$, are observed in CRC patients ${ }^{3}$. Therefore, it appears that CRC develops in an environment of immune misdirection, in which unidentified antigens drive parainflammation while cell-mediated immunity to tumor-associated antigens fails.

The composition of the microbiota and the phenotype of dendritic cells (DC) are altered in $C R C^{4,5,6}$. The intestinal microbiota constantly interacts with the immune system at the mucosal interface, with DC continually sampling contents of the lumen and presenting microbial and food antigens to the lymphocytes situated in mucosal-associated lymphoid tissue. In mouse models, colitis-associated CRC is prevented by T-bet expression in DC which is T-cell-dependent ${ }^{7}$. T-bet ${ }^{+} \mathrm{DC}$ are crucial to initiation of cell-mediated immune responses dominated by $\mathrm{CD} 8^{+} \mathrm{T}$ cells. $\mathrm{CD} 8^{+} \mathrm{T}$ cells are a prominent tissueresident population within the gut mucosa, being abundant in both the epithelium and lamina propria. $\gamma \delta \mathrm{T}$ cells are another prominent $\mathrm{T}$ cell population making up intraepithelial lymphocytes (IEL), expressing a natural tissue-resident phenotype, and are crucial to tumor surveillance due to their ability to kill tumor cells irrespective of conventional MHC class I restriction and dependent on their unconventional receptor specificities ${ }^{8} . \gamma \delta$ T cells can respond to microbes via Toll-like receptors or via epithelial cells, to maintain barrier function and tissue repair 9 .

Resident memory T cells (Trm), which are non-circulating CD103- and CD69-expressing cells, can reside in both mucosal tissue and within tumors. High numbers of Trm within tumor tissue are associated with a good prognosis ${ }^{10}$. Tumor Trm cells are believed to strongly adhere to their target tumor cells via CD103 binding to its ligand E-cadherin, expressed on epithelial cells ${ }^{11}$. Precursors of Trm may traffic from blood to the inflamed tumor environment and develop Trm-like characteristics, with antigen specificities that may include tumor-associated markers or antigens originating from the tumorassociated microbiota. In IBD, loss of $\gamma \delta$ and Trm populations is associated with abnormal B cell responses to the microbiota, especially in Crohn's disease ${ }^{12}$. This suggests that poor cell-mediated immunity results in increased microbial translocation into gut tissues and uncontrolled $B$ cell responses. Since a disturbed microbiota is associated with both IBD and CRC, and IEL are closely associated with, and respond to, microbial antigens from the microbiota, we set out to test the hypothesis that $\gamma \delta$ or Trm populations in the non-lesional mucosa of CRC-susceptible individuals are involved in development of parainflammation and/or tumorigenesis. Ours is the first study to associate depletion of these immune populations with $\mathrm{CRC}$ and to identify $\mathrm{B}$ cell dysfunction as a potential contributor to parainflammation. 
medRxiv preprint doi: https://doi.org/10.1101/2021.02.15.21251750; this version posted February $19,2021$. The copyright holder for this preprint (which was not certified by peer review) is the author/funder, who has granted medRxiv a license to display the preprint in perpetuity.

It is made available under a CC-BY 4.0 International license .

Our data implicate a dysfunctional relationship between the immune system and microbiota in the loss of tissue-resident populations which are critical in tumor immune surveillance. The results identify novel immune markers in tissue and blood that associate with susceptibility to CRC.

\section{Materials and Methods}

\section{Study Design}

Donors (age 16-80 years) were recruited from St Mark's Hospital, the UK national bowel hospital, and included patients undergoing surgery for $\mathrm{CRC}$ and healthy donors undergoing investigative endoscopy. Patients were recruited between June 2018 and October 2019; no data were excluded at the end of the study. Clinical and demographic patient characteristics are shown in Table 1. Surgical tissue from the left colon and/or $20 \mathrm{ml}$ peripheral blood was obtained from participants. Surgery patients were treated with antibiotics (neomycin) and mechanical bowel preparation (laxatives), as part of routine bowel preparation within the 24-hour period prior to surgery. Healthy gut tissue donors received mechanical bowel preparation only. Additional healthy blood donors were recruited from hospital staff and visitors. Ethical approval was obtained from the Health Research Authority UK and London-Harrow Research Ethics Committee (study ref 17/LO/1636). Written informed consent was received from participants prior to inclusion in the study.

Colonic intraepithelial lymphocytes (IEL), lamina propria lymphocytes (LPL) and intraepithelial microbe (IEM) isolation/characterization

For some CRC patients, 5 left colon mucosal biopsies (10 $\mathrm{mg}$ tissue each) were obtained from macroscopically non-lesional tissue sites of CRC surgical tissue post resection. For healthy control tissue donors, five $10 \mathrm{mg}$ left colon biopsies were obtained from macroscopically non-lesional tissue sites during routine colonoscopy. IEL and IEM were released from biopsies using DTT/EDTA and harvested by centrifugation at $300 \mathrm{~g}(5 \mathrm{~min})$. IEM were obtained by centrifugation of resulting supernatants at $4500 \mathrm{~g}$ (20 min). LPL were obtained by digestion with collagenase of remaining tissue. All cells were washed, then phenotyped and counted by flow cytometry. Cells were first stained for viability using LIVE/DEAD Fixable-near-IR stain (ThermoFisher) before addition of surface-staining antibodies in fetal calf serum. In some cases, cells were then fixed/permeabilized for intranuclear staining using the Foxp3 buffer set (ThermoFisher, as instructions). Cells were stained with antibodies to $\gamma \delta \mathrm{TCR}, \mathrm{CD} 4, \mathrm{CD} 8, \mathrm{CD} 103, \mathrm{CD} 69, \mathrm{CD} 39$ and CD73 (supplementary Table 1). All samples were acquired on a BD Biosciences FACS Canto II flow cytometer and data analyzed by FlowJo software (Tree Star), with volumetric sampling determined using Perfect-Count microspheres ${ }^{\mathrm{TM}}$ (Cytognos, S.L).

\section{Commensal-specific $T$ and $B$ cell memory proliferative responses}

Commensal species were isolated from the cecum of healthy donors ${ }^{13,14}$. Strains were grown anaerobically in Hungate tubes containing Wilkins-Chalgren broth $\left(37^{\circ} \mathrm{C}\right.$ for $\left.24 \mathrm{~h}\right)$. Aliquots $(1 \mathrm{ml})$ were centrifuged (13,000 rpm for $10 \mathrm{~min}$ ), supernatants removed and cell pellets snap-frozen on dry ice 
medRxiv preprint doi: https://doi.org/10.1101/2021.02.15.21251750; this version posted February $19,2021$. The copyright holder for this preprint (which was not certified by peer review) is the author/funder, who has granted medRxiv a license to display the preprint in perpetuity.

It is made available under a CC-BY 4.0 International license .

before storage at $-80^{\circ} \mathrm{C}$. Yeast strains were isolated from a stool sample collected from a healthy young infant donor. Strains were grown statically in yeast-extract peptone (YPD) broth $\left(37^{\circ} \mathrm{C}\right.$ for $\left.72 \mathrm{~h}\right)$. Aliquots $(1 \mathrm{ml})$ were centrifuged (1000 $\mathrm{g}$ for $15 \mathrm{~min}$ ), supernatants removed and cells resuspended in an equal volume of PBS. Yeast cells were killed by heat treatment $\left(70^{\circ} \mathrm{C}\right.$ for $\left.3 \mathrm{~h}\right)$ and heat-treated cell suspensions were stored at $4{ }^{\circ} \mathrm{C}$ until required. PBMC were obtained over Ficoll gradients and labelled with CellTrace Violet ${ }^{\mathrm{TM}}(1 \mu \mathrm{M}$, Life Technologies) according to manufacturer's instructions, then cultured at $4 \times 10^{6} / \mathrm{ml}$ in XVIVO15 serum-free medium (Lonza, $+50 \mu \mathrm{g} / \mathrm{ml}$ gentamycin (Sigma) and penicillin/streptomycin (ThermoFisher, 1/100)). Killed cells $\left(2 \times 10^{5}\right)$ from 9 bacterial species and two fungal species (listed in Fig 4 ) were added to $0.2 \mathrm{ml}$ cultures and microbe-specific $\mathrm{CD} 4^{+} / \mathrm{CD}^{+} \mathrm{T}$ cell and $B$ cell proliferative responses were determined after 7 days culture. Cultured cells were analyzed by staining with LIVE/DEAD stain and CD4/CD8/CD19 antibodies (supplementary Table 1).

Measurement of antibody responses

IEM were labelled with SYBR Green DNA stain (ThermoFisher, 1/100,000), anti-IgA-APC/anti-IgG$\mathrm{APC} / \mathrm{Cy} 7$ and analyzed by flow cytometry to determine proportions (\%) of bacteria coated with antibodies in the gut. Intact microbes were gated according to SYBR Green staining.

\section{Statistical analysis}

GraphPad Prism 9 software (GraphPad, San Diego, CA) was used to plot and analyze the data, using Mann Whitney non-parametric tests. For proliferation data Kruskal-Wallis ANOVA was used, with correction for multiple comparisons applied using the Benjamini, Krieger \& Yekutieli method. P values less than 0.05 were considered significant and indicated by: ${ }^{*}, p<0.05 ;{ }^{* *}, p<0.01 ;{ }^{* * *}, p<0.001$.

\section{Results}

$\gamma \delta T$ cells with residence markers and $C D 8^{+}$and $C D 4^{+}$Trm are deficient in CRC mucosa

$\gamma \delta \mathrm{T}$ cells and resident memory $\mathrm{T}$ cells were identified in both IEL and LPL from healthy colonic endoscopic biopsies using the extracellular markers CD103 and CD69 and the intranuclear transcription factor Runx $3^{15}$ (Figure 1). IEL consisted of $\gamma \delta \mathrm{T}$ cells and CD8 ${ }^{+} \mathrm{T}$ cells, the majority of which expressed both CD103 and CD69 and were therefore classed as a tissue resident phenotype. Consistent with our previous study ${ }^{12}, \mathrm{CD}_{103^{+}} \mathrm{T}$ cells preferentially expressed $\mathrm{CD} 39$, a regulatory $\mathrm{T}$ cell-associated ectonucleotidase not present on circulating $\mathrm{T}$ cells. Indeed, Trm express both pro-inflammatory and regulatory features ${ }^{12}$. Among LPL, $\gamma \delta$ T cells were rare and large numbers of CD4 and CD8 T cells were present, lower proportions of which expressed CD103 and CD39 compared to IEL although CD69 was still present (Figure 1a). Runx3, the transcription factor that drives Trm differentiation ${ }^{15}$, was absent in LPL but could be seen at high levels in some $\gamma \delta$ T cells and at lower levels in most (50-80\%) CD8 $8^{+}$IEL (Figure 1b). 
medRxiv preprint doi: https://doi.org/10.1101/2021.02.15.21251750; this version posted February $19,2021$. The copyright holder for this preprint (which was not certified by peer review) is the author/funder, who has granted medRxiv a license to display the preprint in perpetuity.

It is made available under a CC-BY 4.0 International license .

We then analyzed the presence of $\gamma \delta$ T cells and Trm in non-affected colonic mucosa from CRC patients, to test the hypothesis that there is an underlying and detectable susceptibility to tumorigenesis in colonic tissue. Surgical tissue was used as a source of mucosal biopsies, taken by forceps in a manner as comparable as possible to biopsy via endoscopy. Numbers and proportions of tissueresident mucosal T cells are shown in Figure 2, using CD103 as the defining marker. Both total numbers of $T$ cells and percentages of total cells (which included epithelial cells) were dramatically reduced in $\mathrm{CRC}$ biopsies compared to those from healthy donors. This was the case for all CD103-expressing cells including $\gamma \delta \mathrm{T}$ cells in IEL, CD8 ${ }^{+}$Trm in IEL and LPL, and CD4+ Trm in LPL, proportions of which in CRC samples represented on average $14 \%, 15 \%, 9.0 \%$ and $5.5 \%$ of those in healthy donors, respectively. Furthermore, the proportion of cells expressing CD103 within each subset was significantly reduced in CRC patients (with the exception of $C D 8^{+} \mathrm{Trm}$ in LPL which did not reach statistical significance) (Figure 2a-d). Thus, CRC tissue exhibits a profound and selective depletion of tissue resident lymphocytes, which is comparable, though more extreme, than that we have described in IBD ${ }^{12}$. Only one of the CRC patients had been diagnosed with IBD (Crohn's disease). The depletion could not be accounted for by a concentration of $T$ cells in tumor tissue itself, as this contained similar numbers of T cells to surrounding tissue (unpublished observation). Furthermore, depletion of the same populations was seen in pre-cancerous individuals with familial adenomatous polyposis (unpublished data), indicating that immune dysfunction precedes tumorigenesis.

We also analyzed expression of regulatory $T$ cell markers on tissue resident cells (Figure 2e). We included CD73 as well as CD39, as it is also involved in extracellular ATP degradation to adenosine and regulatory function ${ }^{16}$ but is not selectively expressed on $\mathrm{Trm}^{12}$. Amongst $\mathrm{LPL}$, reduced proportions of $\mathrm{CD}^{+}{ }^{+}$Trm cells expressing both CD39 and CD73 were found in CRC. A similar trend (though not significant for CD73), was apparent in $\mathrm{CD}^{+} \mathrm{Trm}$. Due to the extremely low numbers of cells detected in CRC tissue, expression of these markers in IEL could not be accurately compared. The data suggest some loss of regulatory $\mathrm{T}$ cell function in CRC-susceptible mucosa, perhaps secondary to an altered microbiota.

\section{Antibody responses to mucosa-associated bacteria are unaltered in CRC}

IEM released from colonic biopsies were assessed for levels of IgA and IgG coated microbes, to determine whether there is an upregulated immune response to the intestinal microbiota in CRC, as we have described in IBD ${ }^{12}$. Interestingly, there was no significant difference in levels of either IgA or IgG coating in CRC compared to healthy controls, although the total numbers of IEM were reduced (Figure 3). A subset of 4 CRC patients had abnormally high IgG, but not IgA coating of their IEM, perhaps suggesting damage to the intestinal barrier.

$T$ cell memory to commensal bacteria and fungi is perturbed while B cell memory is increased in CRC

To further assess microbiota:immune system interactions in CRC, we examined circulating acquired memory responses to a panel of 9 commensal intestinal (upper gut) bacteria and two intestinal yeast strains, using PBMC from CRC donors and healthy controls (HC). The bacterial strains were selected 
medRxiv preprint doi: https://doi.org/10.1101/2021.02.15.21251750; this version posted February $19,2021$. The copyright holder for this preprint (which was not certified by peer review) is the author/funder, who has granted medRxiv a license to display the preprint in perpetuity.

It is made available under a CC-BY 4.0 International license .

from a previously described panel based on their relatively high immunogenicity in an initial panel of 1912. Patterns of positive $T$ cell and $B$ cell proliferative responses to each strain showed a large degree of donor variability in both $\mathrm{HC}$ and $\mathrm{CRC}$, with as expected, $\mathrm{CD} 4^{+} \mathrm{T}$ cell responses predominating (Figure 4). The overall levels of proliferation in $\mathrm{CD} 4^{+} \mathrm{T}$ cells showed a statistically significant difference between $\mathrm{HC}$ and $\mathrm{CRC}$, although none of the comparisons for individual species were significant. The results were similar for $\mathrm{CD} 8^{+} \mathrm{T}$ cells, except that $\mathrm{CD} 8$ memory to Staphylococcus epidermidis was close to being significantly weaker in CRC than $\mathrm{HC}$. By contrast, a dramatic difference was seen in $\mathrm{B}$ cell proliferative responses, with significantly greater B cell immunity to 5 of the 9 bacterial strains and also to Candida albicans, a yeast commonly found in the gut, in CRC. Overall levels of B cell response showed a statistically significant difference between $\mathrm{HC}$ and $\mathrm{CRC}$, reflecting dysregulated $\mathrm{B}$ cell memory to both commensal bacteria and yeast.

\section{Circulating transitional B cells, plasmablasts and effector memory B cells are increased in CRC}

Since B cell memory to microbiota appeared dysregulated in CRC, we performed a global analysis of peripheral $B$ cell subsets to further define perturbations of $B$ cell homeostasis as potential biomarkers of $\mathrm{CRC}$. We stained PBMC for naïve vs memory and effector memory B cell subsets, along with IgAand IgG-switched B cells, plasmablasts and transitional B cells (T1 and T2). The data (Figure 5a and b) showed that overall proportions of memory $B$ cells were not different between $\mathrm{HC}$ and CRC PBMC. However, proportions of effector memory $B$ cells and plasmablasts (the most activated subsets) were significantly higher in CRC than HC. T1 and T2 transitional B cells, which are thought to be immature naïve $B$ cells with high levels of autoreactivity ${ }^{17}$, were both found at higher levels in CRC than HC. There was no evidence of increased $B$ cell switching to $\lg A$ or $\lg G$ from $\operatorname{lgM}$. The activated signature of peripheral $B$ cells in CRC led us to speculate whether they might contribute to the inflammation reported in $\mathrm{CRC}$ and other cancers ${ }^{3,18}$. We found that $\mathrm{B}$ cells from healthy donors activated overnight with PMA and ionomycin were indeed capable of producing both IFN- $\gamma$ and TNF- $\alpha$ (Figure 5c), two proinflammatory cytokines present at higher levels in the circulation of CRC patients ${ }^{3}$.

\section{Discussion}

Identification of novel immune markers in tissue or blood that associate with "poor gut health" and susceptibility to CRC is of potential clinical value in prophylaxis and therapy. We describe an immune profile in CRC distinct from that in IBD that could be of use to identify IBD patients at highest risk of CRC.

A goal of tumor immunotherapy is to accelerate the generation of $T$ cells with specificities capable of eliminating tumor cells, by blocking natural checkpoint inhibition pathways which prevent development of effector T cells with self-specificity. However, it is appreciated that there is a background level of antitumor immunity present in tissue, reflected by the large numbers of tissue resident lymphocytes in mucosal tissues at high risk of malignant transformation, such as the colon. $\gamma \delta$ T cells have long been 
medRxiv preprint doi: https://doi.org/10.1101/2021.02.15.21251750; this version posted February $19,2021$. The copyright holder for this preprint (which was not certified by peer review) is the author/funder, who has granted medRxiv a license to display the preprint in perpetuity.

It is made available under a CC-BY 4.0 International license .

known to reside mainly in peripheral tissues and have anti-tumorigenic effects through unconventional specificities $^{19}$. It appears that $\gamma \delta$ T cells are the most effective cell type in tumor eradication ${ }^{20}$, due to their ability to recognize self-antigens whilst also retaining a degree of receptor variability. Their tissuesensing capacity means that they are not dependent on the high mutational loads needed to generate peptide neoantigens for tumor recognition by conventional T cells ${ }^{19}$. Additionally, $\gamma \delta \mathrm{T}$ cells can respond to endogenous sterol intermediates which are expressed in malignant and virus-infected cells ${ }^{21}$. Our finding that these cells are deficient in CRC is therefore significant. The factors that sustain $\gamma \delta \mathrm{T}$ cells within specific tissues are unclear. However, it has been shown in mice that butyrophilin expression on intestinal epithelial cells is involved in the development of $\gamma \delta \mathrm{IEL}{ }^{22}$, pointing towards interactions between epithelium and $\gamma \delta$ T cells that could be dysregulated in CRC. Retinoic acid, an important mediator of $\mathrm{T}$ cell recruitment to the intestinal mucosa ${ }^{23}$, is deficient in colitis-associated $\mathrm{CRC}^{24}$ and also enhances IL-22 secretion from $\gamma \delta$ T cells, which suppresses intestinal inflammation ${ }^{25}$. Furthermore, $\gamma \delta \mathrm{T}$ cell migration around intestinal villi is able to block translocation of pathogenic microbes ${ }^{26}$. Further research is required to determine how IEL populations can be boosted in order to maintain health ${ }^{27}$.

More recently, the definition of Trm as a distinct subset, residing for long periods in the epithelium and lamina propria of the colon, has expanded the repertoire of potential tissue-protective cells during homeostasis. The role of the intestinal microbiota, however, in the etiology of CRC is only beginning to become recognized ${ }^{28}$. The interplay between resident lymphocytes and the microbiota is the dominant feature of the colonic epithelium where tumors develop, and CRC has now been added to the growing list of diseases associated with an abnormal intestinal microbiome ${ }^{29}$. Moreover, developing tumors harbor their own microbiota ${ }^{30}$ and the Trm within tumors are associated with positive outcomes, suggesting that these cells can either prevent tumorigenesis or can expand in response to tumor- or microbiota-associated antigens during the course of the disease and kill target cells ${ }^{31}$.

The profound depletion of $\gamma \delta \mathrm{T}$ cells and Trm in the mucosa of CRC patients that we describe here suggests that there is an inherent susceptibility to tumorigenesis in these patients, linked to environmental or microbiota-related factors. Most patients were experiencing primary disease and had not received treatment with immunosuppressive agents or other medications that may have confounded the data, with the exception of pre-surgical antibiotic therapy. However, the latter was administered within the 24 hours prior to surgery so may not have impacted mucosal populations. Our observations that a similar paucity of IEL is seen in IBD patients, who are at increased risk of CRC, suggests that maintaining populations of $\gamma \delta$ T cells and Trm at levels in seen healthy individuals is essential for maintaining homeostasis, blocking cell transformation and preventing inappropriate inflammation. Importantly, the expression of regulatory T cell molecules CD39 and CD73 on $\gamma \delta \mathrm{T}$ cells and Trm, including CD4 Trm in LPL, was reduced in CRC patients, strengthening the inference that immune barrier function and homeostasis are compromised in those developing CRC. The altered phenotype of mucosal CD4 T cells may also contribute to the dysregulation in B cell responses, since these depend on CD4 T cell "help", balanced by CD4 regulatory T cell activity. $\gamma \delta \mathrm{T}$ cells are also known to have regulatory function which may balance their potent cytotoxic functions when present in tumor tissue ${ }^{32,33}$. 
medRxiv preprint doi: https://doi.org/10.1101/2021.02.15.21251750; this version posted February 19, 2021. The copyright holder for this preprint (which was not certified by peer review) is the author/funder, who has granted medRxiv a license to display the preprint in perpetuity.

It is made available under a CC-BY 4.0 International license .

These regulatory activities may suppress microbiota-dependent inflammation through the degradation of extracellular ATP released by microbes and activated immunocytes ${ }^{34,35,36}$, which we speculate also protects from parainflammation.

Impaired immune barrier function has been described as a consequence of aging or inflammation and is associated with $\mathrm{CRC}^{37}$. Although inflammation seen in $\mathrm{CRC}$ patients is not accompanied by increased secretory IgA synthesis against mucosa-associated microbes, we detected a strong B cell activation signal in CRC that was comparable to that seen in IBD. It is therefore possible that there is increased translocation or sampling of microbes by $D C$ in the mucosa prior to tumorigenesis, perhaps triggered by an altered microbiota with expanded pathobiont species. Increased access of microbial antigens to mucosa-associated lymphoid tissue and mesenteric lymph nodes could have resulted in the increased $B$ cell memory responses to a variety of commensal species, as well as the global activation of circulating $B$ cells that we describe in CRC. Increased memory B cells and plasmablasts have previously been reported in $\mathrm{CRC}$ and shown to be present in tumor infiltrates ${ }^{38}$. Furthermore, the ability of $\mathrm{B}$ cells to secrete pro-inflammatory cytokines implicates them as a direct mediator of parainflammation, although there are numerous other potential cellular sources of these cytokines which have not been identified ${ }^{39}$.

In addition to the effector memory B cells and plasmablasts, which we identified as biomarkers in the blood, we also demonstrated increased proportions of transitional B cells in CRC patients. Transitional $B$ cells are recent emigrants from bone marrow and are enriched in autoreactive cells ${ }^{40}$. Furthermore, intestinal tissue has been proposed as a site to which transitional B cells migrate and are selected to remove autospecificities, a process that is defective in systemic lupus erythematosus leading to uncontrolled autoantibody production ${ }^{41}$. Autoantibodies to tumor antigens are a known early indicator of $\mathrm{CRC}^{42}$. Therefore, perturbation of $\mathrm{B}$ cell repertoire selection by low-level barrier dysfunction in early $\mathrm{CRC}$, as suggested by our data, may prevent negative selection of $\mathrm{B}$ cells specific for autoantigens and expand B cell clones reactive to microbiota-derived antigens. This, to our knowledge, is the first study to identify transitional B cell involvement in a non-B cell malignancy. It may point towards a common mechanism leading to loss of $B$ cell tolerance towards both tumor-associated and microbial antigens during $C R C$ etiology. This area clearly requires further investigation and mechanistic data acquired from animal models. Interestingly, in CRC the IgA responses to epithelia-associated microbes were unchanged, a result that contrasts with that in IBD patients ${ }^{12}$. Therefore, more overt mucosal inflammatory signals may be required before the secretory IgA pathway is disturbed.

Overall, our novel observations of altered microbiota:immune system interaction in CRC suggest that depleted gut-resident immune cells in genetically susceptible individuals may drive parainflammation and compromise immune surveillance in the intestinal mucosa, providing new insights into disease etiology. The activated B cell signature we have identified in CRC may prove useful in identifying highrisk individuals, while the profound deficiency in IEL emphasizes the importance of strategies that boost intestinal cellular immunity for prophylaxis. Our data also strengthen the rationale for developing $\gamma \delta T$ cell therapy for treatment of cancer ${ }^{43}$. 
medRxiv preprint doi: https://doi.org/10.1101/2021.02.15.21251750; this version posted February 19, 2021. The copyright holder for this preprint (which was not certified by peer review) is the author/funder, who has granted medRxiv a license to display the preprint in perpetuity.

It is made available under a CC-BY 4.0 International license .

\section{Acknowledgements}

We thank Alison Scoggins for administrative assistance. We are grateful to the staff and patients of St Mark's Hospital and our blood donors for their participation in this study.

\section{References}

1. Hnatyszyn, A. et al. Colorectal carcinoma in the course of inflammatory bowel diseases. Hered Cancer Clin Pract 17, 18 (2019).

2. Balkwill, F.R. \& Mantovani, A. Cancer-related inflammation: common themes and therapeutic opportunities. Semin Cancer Biol 22, 33-40 (2012).

3. Crucitti, A. et al. Laparoscopic surgery for colorectal cancer is not associated with an increase in the circulating levels of several inflammation-related factors. Cancer Biol Ther 16, 671-677 (2015).

4. Wang, T. et al. Structural segregation of gut microbiota between colorectal cancer patients and healthy volunteers. ISME J 6, 320-329 (2012).

5. Tjalsma, H., Boleij, A., Marchesi, J.R. \& Dutilh, B.E. A bacterial driver-passenger model for colorectal cancer: beyond the usual suspects. Nat Rev Microbiol 10, 575-582 (2012).

6. Legitimo, A., Consolini, R., Failli, A., Orsini, G. \& Spisni, R. Dendritic cell defects in the colorectal cancer. Hum Vaccin Immunother 10, 3224-3235 (2014).

7. Garrett, W.S. et al. Colitis-associated colorectal cancer driven by T-bet deficiency in dendritic cells. Cancer Cell 16, 208-219 (2009).

8. Maeurer, M.J. et al. Human intestinal Vdelta1 ${ }^{+}$lymphocytes recognize tumor cells of epithelial origin. J Exp Med 183, 1681-1696 (1996).

9. Yang, Y. et al. gamma delta T Cells: crosstalk between microbiota, chronic inflammation, and colorectal cancer. Front Immunol 9, 1483 (2018).

10. Ganesan, A.P. et al. Tissue-resident memory features are linked to the magnitude of cytotoxic T cell responses in human lung cancer. Nat Immunol 18, 940-950 (2017).

11. Amsen, D., van Gisbergen, K., Hombrink, P. \& van Lier, R.A.W. Tissue-resident memory T cells at the center of immunity to solid tumors. Nat Immunol 19, 538-546 (2018).

12. Noble, A. et al. Deficient resident memory T Cell and CD8 T cell response to commensals in inflammatory bowel disease. J Crohns Colitis 14, 525-537 (2020).

13. Hoyles, L. et al. Klebsiella pneumoniae subsp. pneumoniae-bacteriophage combination from the caecal effluent of a healthy woman. PeerJ 3, e1061 (2015).

14. Hoyles, L. et al. Metabolic retroconversion of trimethylamine N-oxide and the gut microbiota. Microbiome 6, 73 (2018). 
medRxiv preprint doi: https://doi.org/10.1101/2021.02.15.21251750; this version posted February 19, 2021. The copyright holder for this preprint (which was not certified by peer review) is the author/funder, who has granted medRxiv a license to display the preprint in perpetuity.

It is made available under a CC-BY 4.0 International license .

15. Milner, J.J. et al. Runx3 programs CD8 ${ }^{+}$T cell residency in non-lymphoid tissues and tumours. Nature 552, 253-257 (2017).

16. Schuler, P.J. et al. Human $\mathrm{CD} 4^{+} \mathrm{CD} 39^{+}$regulatory $\mathrm{T}$ cells produce adenosine upon co-expression of surface CD73 or contact with CD73 ${ }^{+}$exosomes or CD73+ cells. Clin Exp Immunol 177, 531-543 (2014).

17. Nojima, T., Reynolds, A.E., Kitamura, D., Kelsoe, G. \& Kuraoka, M. Tracing self-reactive B cells in normal mice. J Immunol (2020).

18. Chen, J., Pitmon, E. \& Wang, K. Microbiome, inflammation and colorectal cancer. Semin Immunol 32, 4353 (2017).

19. Hayday, A.C. gamma delta T cell update: adaptate orchestrators of immune surveillance. J Immunol 203, 311-320 (2019).

20. Gentles, A.J. et al. The prognostic landscape of genes and infiltrating immune cells across human cancers. Nat Med 21, 938-945 (2015).

21. Gober, H.J. et al. Human T cell receptor gamma delta cells recognize endogenous mevalonate metabolites in tumor cells. J Exp Med 197, 163-168 (2003).

22. Di Marco Barros, R. et al. Epithelia use butyrophilin-like molecules to shape organ-specific gamma delta T cell compartments. Cell 167, 203-218 e217 (2016).

23. Iwata, M. et al. Retinoic acid imprints gut-homing specificity on T cells. Immunity 21, 527-538 (2004).

24. Bhattacharya, $\mathrm{N}$. et al. Normalizing microbiota-induced retinoic acid deficiency stimulates protective CD8 ${ }^{+}$ T cell-mediated immunity in colorectal cancer. Immunity 45, 641-655 (2016).

25. Mielke, L.A. et al. Retinoic acid expression associates with enhanced IL-22 production by gamma delta T cells and innate lymphoid cells and attenuation of intestinal inflammation. J Exp Med 210, 1117-1124 (2013).

26. Edelblum, K.L. et al. gamma delta intraepithelial lymphocyte migration limits transepithelial pathogen invasion and systemic disease in mice. Gastroenterology 148, 1417-1426 (2015).

27. Wilk, M.M. \& Mills, K.H.G. CD4 Trm cells following infection and immunization: implications for more effective vaccine design. Front Immunol 9, 1860 (2018).

28. Grivennikov, S.I. et al. Adenoma-linked barrier defects and microbial products drive IL-23/IL-17-mediated tumour growth. Nature 491, 254-258 (2012).

29. Feng, Q. et al. Gut microbiome development along the colorectal adenoma-carcinoma sequence. Nat Commun 6, 6528 (2015).

30. Viljoen, K.S., Dakshinamurthy, A., Goldberg, P. \& Blackburn, J.M. Quantitative profiling of colorectal cancer-associated bacteria reveals associations between fusobacterium spp., enterotoxigenic Bacteroides fragilis (ETBF) and clinicopathological features of colorectal cancer. PLoS One 10, e0119462 (2015). 
medRxiv preprint doi: https://doi.org/10.1101/2021.02.15.21251750; this version posted February 19, 2021. The copyright holder for this preprint (which was not certified by peer review) is the author/funder, who has granted medRxiv a license to display the preprint in perpetuity.

It is made available under a CC-BY 4.0 International license .

31. Smazynski, J. \& Webb, J.R. Resident memory-like tumor-infiltrating lymphocytes (TILRM): latest players in the immuno-oncology repertoire. Front Immunol 9, 1741 (2018).

32. Peng, G. et al. Tumor-infiltrating gamma delta $\mathrm{T}$ cells suppress $\mathrm{T}$ and dendritic cell function via mechanisms controlled by a unique Toll-like receptor signaling pathway. Immunity 27, 334-348 (2007).

33. Otsuka, A., Hanakawa, S., Miyachi, Y. \& Kabashima, K. CD39: a new surface marker of mouse regulatory gamma delta T cells. J Allergy Clin Immunol 132, 1448-1451 (2013).

34. Schenk, U. et al. Purinergic control of T cell activation by ATP released through pannexin-1 hemichannels. Sci Signal 1, ra6 (2008).

35. Schnurr, M. et al. Extracellular ATP and TNF-alpha synergize in the activation and maturation of human dendritic cells. J Immunol 165, 4704-4709 (2000).

36. Iwase, T. et al. Isolation and identification of ATP-secreting bacteria from mice and humans. J Clin Microbiol 48, 1949-1951 (2010).

37. Ghosh, P. et al. The stress polarity signaling (SPS) pathway serves as a marker and a target in the leaky gut barrier: implications in aging and cancer. Life Sci Alliance 3 (2020).

38. Shimabukuro-Vornhagen, A. et al. Characterization of tumor-associated B-cell subsets in patients with colorectal cancer. Oncotarget 5, 4651-4664 (2014).

39. Rea, I.M. et al. Age and age-related diseases: role of inflammation triggers and cytokines. Front Immunol $9,586(2018)$

40. Agrawal, S., Smith, S.A., Tangye, S.G. \& Sewell, W.A. Transitional B cell subsets in human bone marrow. Clin Exp Immunol 174, 53-59 (2013).

41. Vossenkamper, A. et al. A role for gut-associated lymphoid tissue in shaping the human B cell repertoire. J Exp Med 210, 1665-1674 (2013).

42. Ushigome, M. et al. Multi-panel assay of serum autoantibodies in colorectal cancer. Int J Clin Oncol 23 , 917-923 (2018).

43. Kunkele, K.P. et al. Vgamma9 Vdelta2 T cells: can we re-purpose a potent anti-infection mechanism for cancer therapy? Cells 9 (2020). 


\section{Table 1. Clinical characteristics of CRC and healthy control (HC) participants}

Tissue donors:

$\mathrm{n}$

Male/female

Median age $(95 \% \mathrm{Cl})$ at sampling

\section{Blood donors:}

$\mathrm{n}$

Male/female

Median age $(95 \% \mathrm{Cl})$ at sampling

\section{Type of CRC surgery:}

Total Mesorectal Excision

Pelvic Exenteration

Other

Disease characteristics:

Lymph node involvement

Vascular invasion

Lymphatic invasion

Tumour differentiation - Poor

Tumour differentiation - Moderate

Tumour differentiation - Well/Moderate

Tumour differentiation - Mucinous

Patient: characteristics:

Obesity

Myopenia 
medRxiv preprint doi: https://doi.org/10.1101/2021.02.15.21251750; this version posted February $19,2021$. The copyright holder for this preprint (which was not certified by peer review) is the author/funder, who has granted medRxiv a license to display the preprint in perpetuity.

It is made available under a CC-BY 4.0 International license .

\section{Figure Legends}

Figure 1. Colonic $\gamma \delta T$ cells and Trm expressing the CD103 surface marker and Runx3 transcription factor preferentially express CD39. A: CD8 T-cell and $\gamma \delta$ T-cell populations were identified in IEL fractions (left panels) and CD8 and CD4 T cells were identified in LPL fractions (right panels). Cells were stained for CD69 and CD103 surface Trm markers (upper panels) or CD103 and CD39 (lower panels). B: IEL populations were permeabilized for intranuclear detection of Runx3 transcription factor; no Runx3 was seen in LPL (not shown). All data are from healthy donors and representative of three independent experiments.

Figure 2. CRC is associated with depletion of $\gamma \delta$ T-cells and Trm in colonic tissue and deficient regulatory function in CD4 Trm. A: Numbers and percentages of $\gamma \delta \mathrm{CD} 103^{+} \mathrm{T}$-cells in IEL, alongside proportion of CD103 expression on total $\gamma \delta$ T cells in healthy control $(\mathrm{HC})$ and colorectal cancer $(\mathrm{CRC})$ groups. B: Numbers and percentages of $\mathrm{CD}^{+} \gamma \delta \mathrm{TCR}^{-} \mathrm{CD} 103^{+}$Trm in IEL, alongside proportions expressing CD103 of total CD8 T cells. C: Numbers and percentages of CD4 ${ }^{+}$CD $103^{+}$Trm in LPL, alongside proportions expressing CD103 of total CD4 T cells. D: Numbers and percentages of CD8 ${ }^{+}$ CD103 ${ }^{+}$Trm in LPL, alongside proportions expressing CD103 of total CD8 T cells. E: Expression of regulatory T cell markers CD39 and CD73 on CD4 and CD8 Trm in LPL. HC: healthy controls, $n=13$; CRC: colorectal cancer, $n=12$. Median values $\pm 95 \%$ confidence intervals are shown; statistically significant differences between groups (Mann Whitney tests) are indicated.

Figure 3. Antibody responses to mucosal-associated microbes are unchanged in CRC patients. IgA and IgG coating levels of IEM obtained from colonic biopsies of HC and CRC donors, after gating on SYBR Green ${ }^{+}$events are shown. Upper graph: numbers of microbes recovered; middle graph: IgA coating; lower graph: IgG coating. Median values $\pm 95 \%$ confidence intervals are shown; statistically significant differences between groups (Mann Whitney tests) are indicated.

Figure 4. $\mathrm{T}$ - and $\mathrm{B}$-cell memory responses to commensal bacteria and intestinal fungi are dysregulated in CRC. A: Heatmaps showing CD4/CD8 T-cell and B cell memory responses to indicated species, obtained from CellTrace Violet dilution data in gated populations of 7-day PBMC cultures with killed antigens. Each column shows results from one donor, with $\mathrm{HC}$ donors to the left and CRC donors to the right of the line. Numbers on scalebar represent \% division. Hatched area: assays not performed. B: Corresponding statistical analysis of data in A, showing overall $p$ value for variance within each subset and comparisons of responses for each individual species below. Kruskal-Wallis ANOVA was used to analyze data with correction for multiple comparisons applied using the Benjamini, Krieger \& Yekutieli method; $n=17 \mathrm{HC}, \mathrm{n}=22 \mathrm{CRC}$.

Figure 5. B-cell dysregulation is a systemic feature of CRC. A: Example of flow cytometric analysis of $B$ cell subsets in PBMC. CD19+ $B$ cells were allocated to naïve, memory and memory effector subsets based on IgD and CD27. Naive $B$ cells were divided into $T 1$ and $T 2$ transitional $B$ cells based on CD38 and CD24 expression. Total $B$ cells were assessed for plasmablasts (CD38 ${ }^{\text {hi }}$ CD2 $7^{+}$CD19 ${ }^{+}$) and 
medRxiv preprint doi: https://doi.org/10.1101/2021.02.15.21251750; this version posted February 19, 2021. The copyright holder for this preprint (which was not certified by peer review) is the author/funder, who has granted medRxiv a license to display the preprint in It is made available under a CC-BY 4.0 International license.

switching to IgA and IgG isotypes. B: Proportions of above subsets in HC vs CRC donor blood. Mann Whitney tests were used to compare groups ( $n=20 \mathrm{HC} ; n=11 \mathrm{CRC}$ ) and statistically significant differences are indicated. C: Intracellular cytokine staining of B cells from HC PBMC before and after stimulation with PMA and ionomycin, showing their capacity for TNF- $\alpha$ and IFN- $\gamma$ production (representative of three independent experiments). 
a

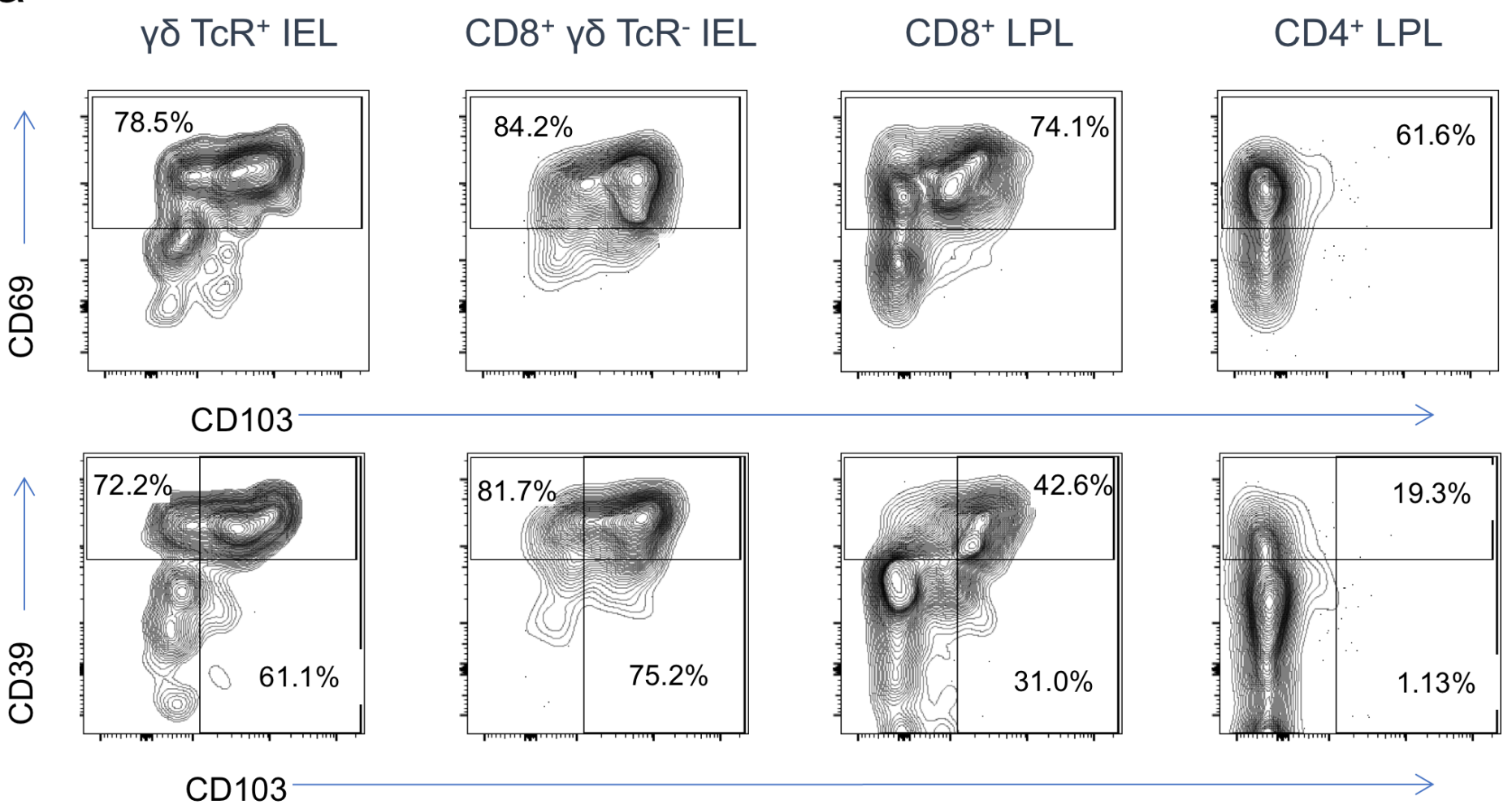

b

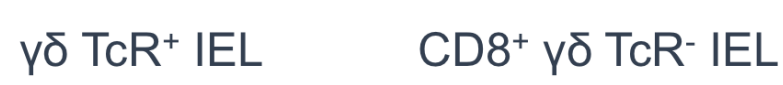
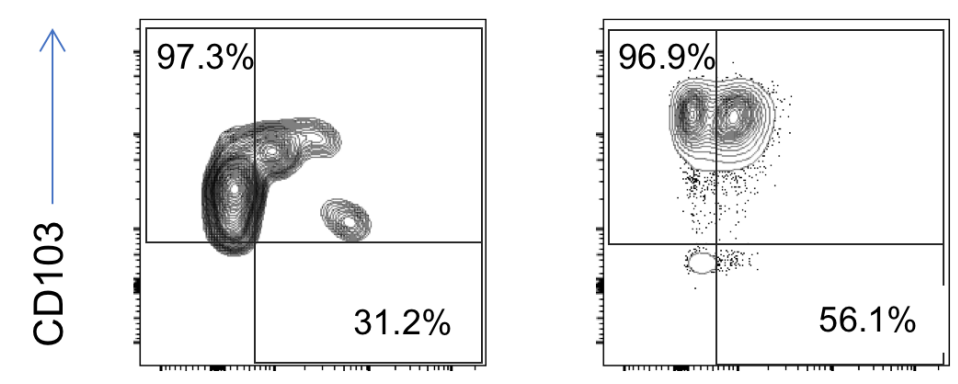

Runx3

Figure 1 

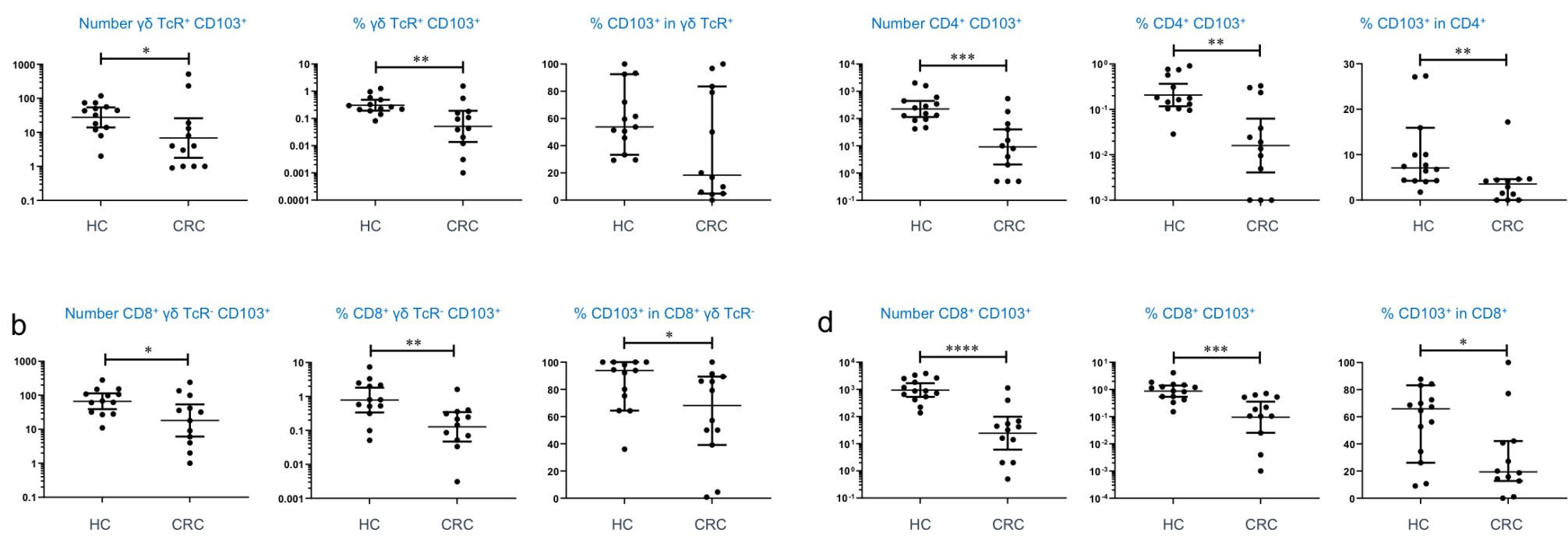

\% $\mathrm{CD}_{103^{+}}$in $\mathrm{CD} 8^{+}$
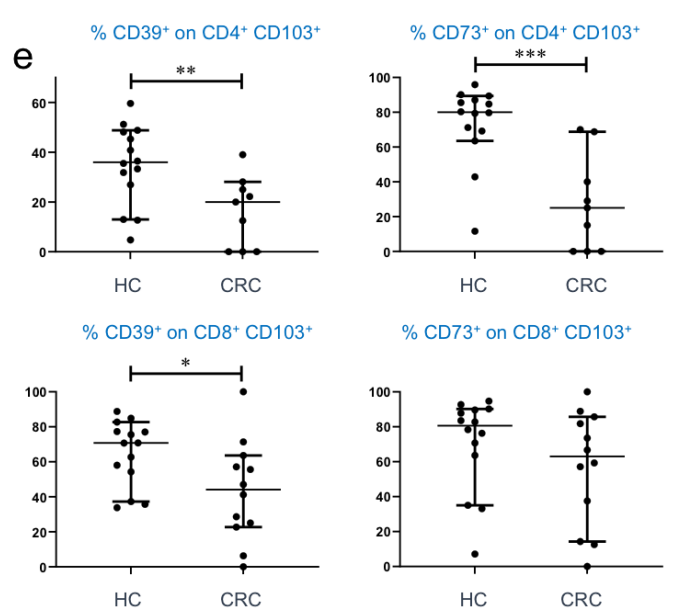

Figure 2 

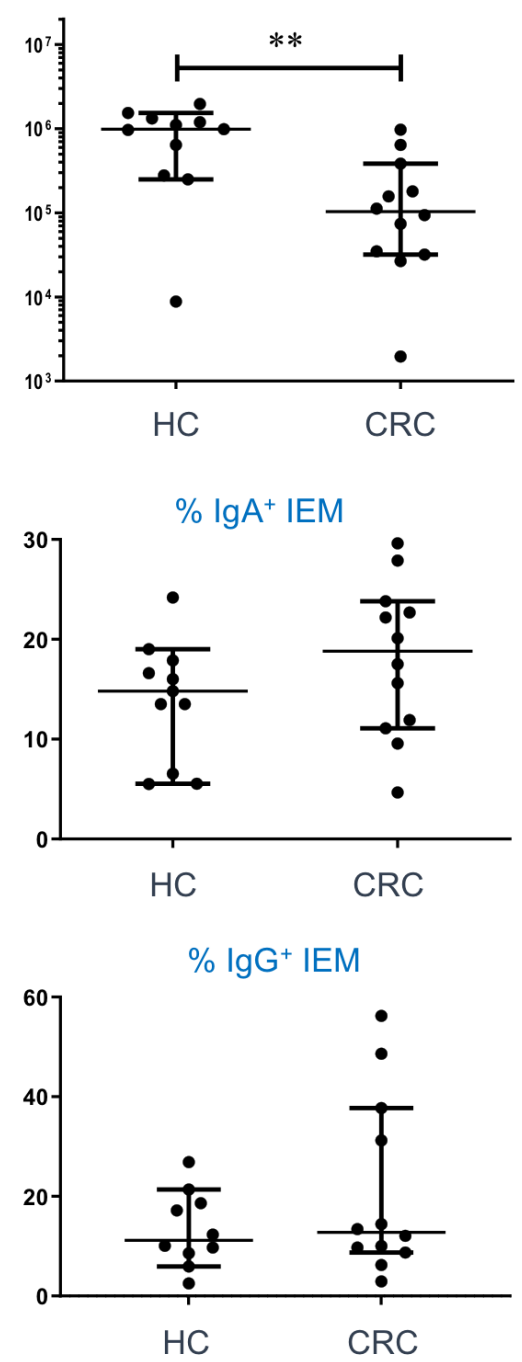

Figure 3 
Schaalia turicensis

Bifido pseudocatenulatum

Clostridium paraputrificum

Escherichia coli

Hafnia paralvei

Staphylococcus epidermidis

Veillonella atypica

Bacillus licheniformis

candida albicans

Candida parapsilosis

unstimulated

$\mathrm{HC}$

$\mathrm{CD}^{+}+\mathrm{T}$ cell \% division

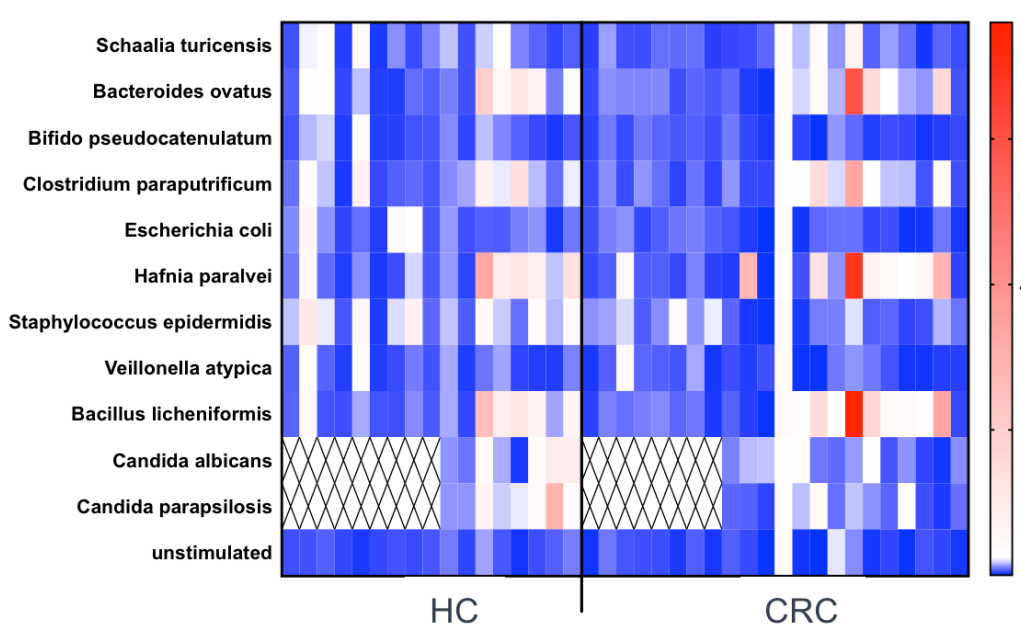

CD19+ $\mathrm{B}$ cell \% division

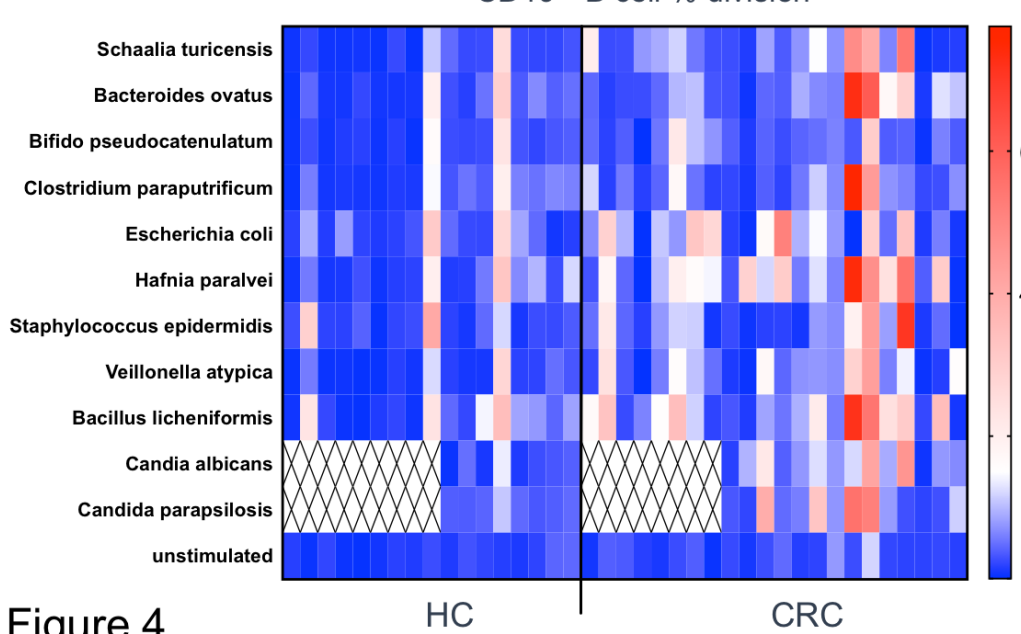

Overall HC vs CRC: $p<0.000$

\begin{tabular}{|l|l|l|}
\hline Comparison & P value & Significance \\
\hline S turicensis HC vs. CRC & 0.9301 & - \\
\hline B ovatus HC vs. CRC & 0.2145 & - \\
\hline B pseudocatenulatum HC vs. CRC & 0.5015 & - \\
\hline C paraputrificum HC vs. CRC & 0.9065 & - \\
\hline E coli HC vs. CRC & 0.9125 & - \\
\hline H paralvei HC vs. CRC & 0.1577 & - \\
\hline S epidermidis HC vs. CRC & 0.6849 & - \\
\hline V atypica HC vs. CRC & 0.7603 & - \\
\hline B licheniformis HC vs. CRC & 0.2703 & - \\
\hline C albicans HC vs. CRC & 0.9297 & - \\
\hline C parapsilosis HC vs. CRC & 0.6712 & - \\
\hline
\end{tabular}

Overall HC vs CRC: $p<0.0001$

\begin{tabular}{|l|l|l|}
\hline Comparison & P value & Significance \\
\hline S turicensis HC vs. CRC & 0.6203 & - \\
\hline B ovatus HC vs. CRC & 0.9684 & - \\
\hline B pseudocatenulatum HC vs. CRC & 0.3740 & - \\
\hline C paraputrificum HC vs. CRC & 0.5285 & - \\
\hline E coli HC vs. CRC & 0.1106 & - \\
\hline Hparalvei HC vs. CRC & 0.7290 & - \\
\hline S epidermidis HC vs. CRC & 0.0555 & \\
\hline Vatypica HC vs. CRC & 0.4700 & - \\
\hline B licheniformis HC vs. CRC & 0.9350 & - \\
\hline C albicans HC vs. CRC & 0.3098 & - \\
\hline C parapsilosis HC vs. CRC & 0.0293 & $\star$ \\
\hline
\end{tabular}

Overall HC vs CRC: $p<0.0001$

\begin{tabular}{|l|l|l|}
\hline Comparison & P value & Significance \\
\hline S turicensis HC vs. CRC & 0.0058 & ** \\
\hline B ovatus HC vs. CRC & 0.0388 & $*$ \\
\hline B pseudocatenulatum HC vs. CRC & 0.1952 & - \\
\hline C paraputrificum HC vs. CRC & 0.1931 & - \\
\hline E colli HC vs. CRC & 0.0913 & - \\
\hline H paralvei HC vs. CRC & 0.0038 & $*$ \\
\hline S epidermidis HC vs. CRC & 0.3045 & - \\
\hline Vatypica HC vs. CRC & 0.0103 & $*$ \\
\hline B licheniformis HC vs. CRC & 0.0299 & $*$ \\
\hline C albicans HC vs. CRC & 0.0242 & $*$ \\
\hline C parapsilosis HC vs. CRC & 0.3860 & - \\
\hline
\end{tabular}


a

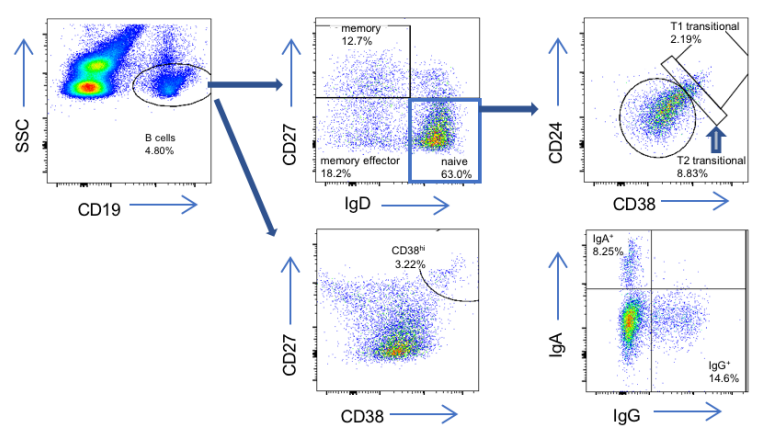

c

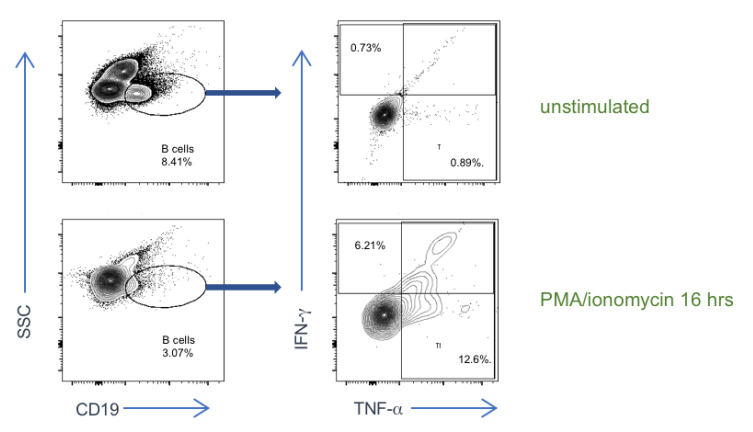

b

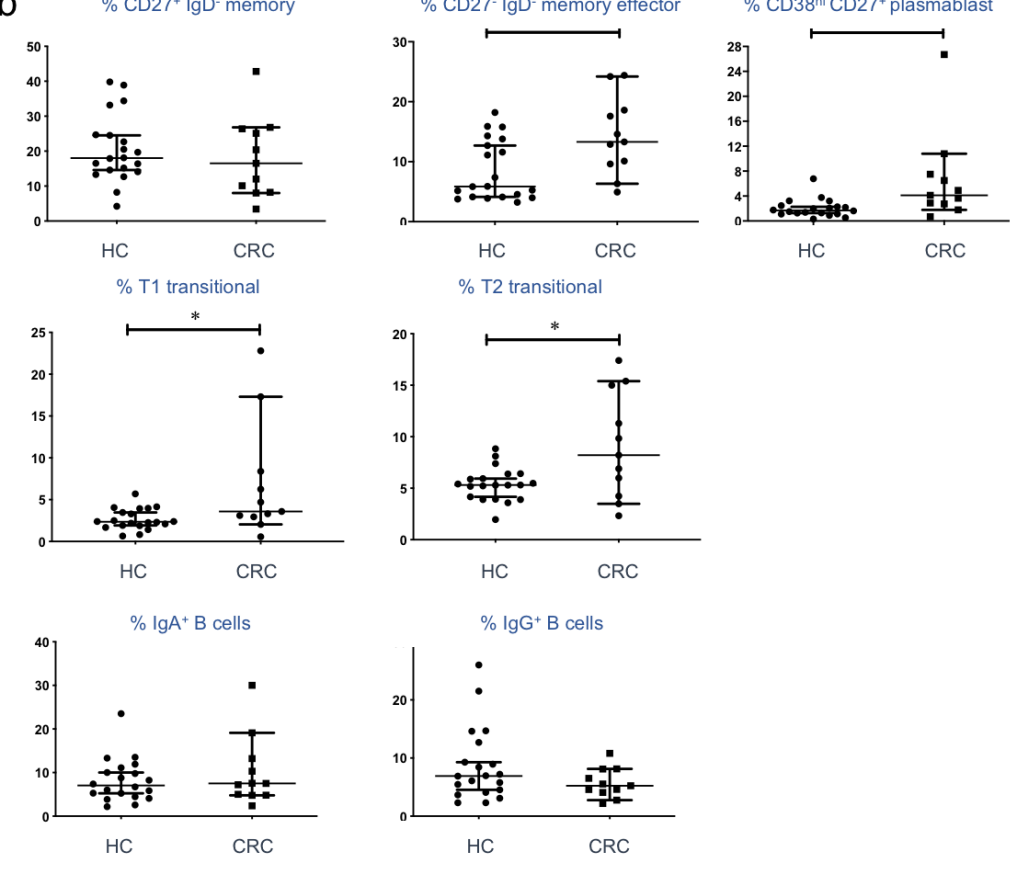

Figure 5 